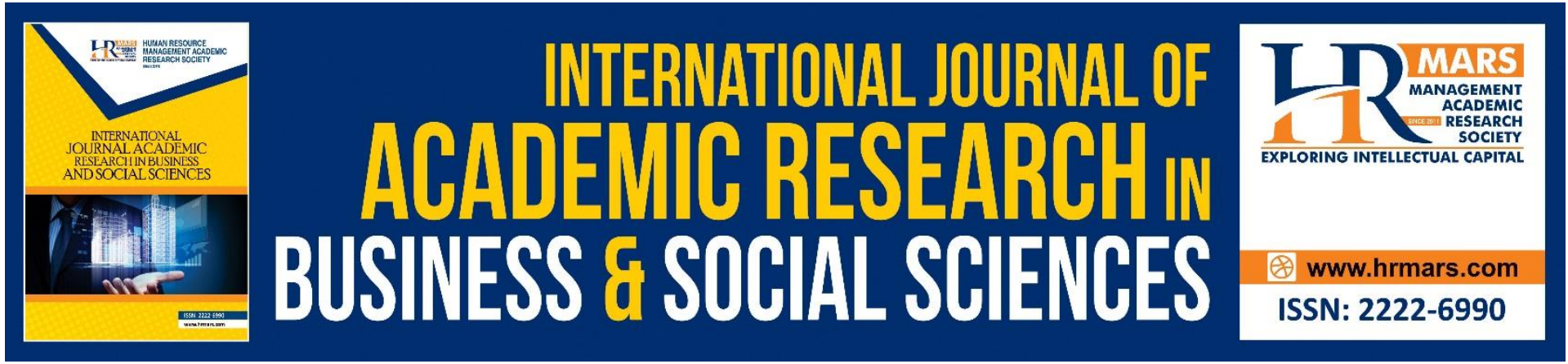

\title{
Knowledge, Attitude and Practices on E-Waste Management among Business Students in A Public University
}

Roslina Md Dan @ Azlan, Siti Suraya Abd Razak, Logaiswari A/P Indiran

To Link this Article: http://dx.doi.org/10.6007/IJARBSS/v11-i8/10609

DOI:10.6007/IJARBSS/v11-i8/10609

Received: 17 June 2021, Revised: 23 July 2021, Accepted: 06 August 2021

Published Online: 25 August 2021

In-Text Citation: (Azlan et al., 2021)

To Cite this Article: Azlan, R. M. D. @, Razak, S. S. A., \& Indiran, L. A. (2021). Knowledge, Attitude and Practices on E-Waste Management among Business Students in A Public University. International Journal of Academic Research in Business and Social Sciences, 11(8), 1472-1478.

Copyright: (c) 2021 The Author(s)

Published by Human Resource Management Academic Research Society (www.hrmars.com)

This article is published under the Creative Commons Attribution (CC BY 4.0) license. Anyone may reproduce, distribute, translate and create derivative works of this article (for both commercial and non-commercial purposes), subject to full attribution to the original publication and authors. The full terms of this license may be seen at: http://creativecommons.org/licences/by/4.0/legalcode

Vol. 11, No. 8, 2021, Pg. 1472 - 1478

http://hrmars.com/index.php/pages/detail/IJARBSS

JOURNAL HOMEPAGE

Full Terms \& Conditions of access and use can be found at

http://hrmars.com/index.php/pages/detail/publication-ethics 


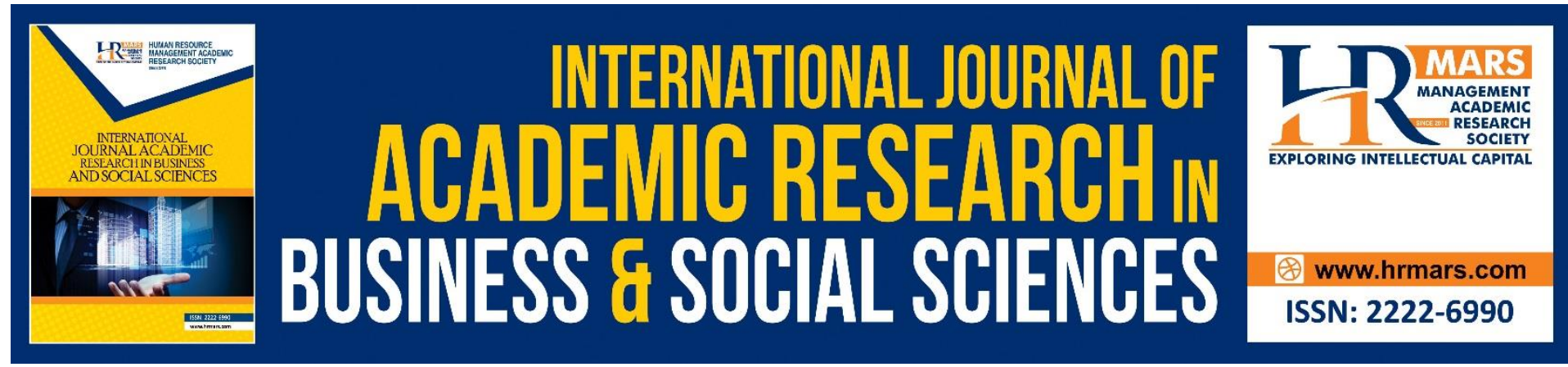

\title{
Knowledge, Attitude and Practices on E-Waste Management among Business Students in A Public University
}

\author{
Roslina Md Dan @ Azlan, Siti Suraya Abd Razak, \\ Logaiswari A/P Indiran \\ Universiti Teknologi Malaysia, 81310, Skudai, Johor Bahru, Malaysia
}

\begin{abstract}
As in many nations, e-waste is an environmental concern in Malaysia. Therefore, effective ewaste management is important to reduce and control pollution. E-waste management awareness is also essential for students as they are using electronic gadgets in their course of studies. However, the knowledge, attitude and awareness e-waste management among students is still lacking. This study aims to examine knowledge, attitude, and practices on ewaste management among business students in a public university. A quantitative method was employed in this study and questionnaires were distributed to collect data from which involved business students in a public university. Findings indicated that business students in the said public university have a moderate level of e-waste management knowledge, attitude, and practices.
\end{abstract}

Keywords: E- Waste, E-Waste Management, Public University, KAP, Environment

\section{Introduction}

Electrical and electronic waste (E-waste) refers to discarded electronic devices and components as well as substances involved in their manufacture or use (Mahat et al., 2019). E-waste is a global problem that negatively impacts human health and the environment. There are two types of e-waste which is known as non-hazardous e-waste and hazardous ewaste. E-waste comprises of different hazardous materials such as cadmium, lead, flame retardants, and other dangerous materials that may spread in the surrounding environment and harm human health if it is not managed properly. E-waste disposal in landfills is not suggested due to the toxic chemicals and heavy metals in it (Kang et al., 2020). A proper ewaste management is vital as each e-waste contains dangerous chemical that is a risk to human health and may cause serious disease such as lung cancer, thyroid and kidney damage. If e-waste is not recycled appropriately and ends up in a landfill, it can further cause environmental pollution (Garlapati, 2016).

The lack of awareness about hazardous e-waste and safe disposal techniques of ewaste is an obstacle in conducting a proper e-waste recycling. According to (Chibunna et al., 2012), the reason for poor awareness on e-waste management is because of the lack of knowledge on how to dispose e-waste. Apart from that, the lack of enforcement by government is one of the contributing factors. According to Cao et al., 2016, most people have 
a preliminary understanding on the hazards caused by e-waste, and they are willing to actively respond to e-waste recycling activities and proposals. In Malaysia, e-waste management is still in its early stages, including the e-waste recycling system (Kalana, 2010, Masud et al., 2019). At the moment, e-waste management in Malaysia is very challenging and often emerges as a national issue (Malaysia Department of Environment, 2013). E-waste management is currently regulated under Environmental Quality Act 1974 (EQA 1974) and under the supervision of Department of Environment Malaysia (DOE). According to the EQA 1974 it is prohibited to discard e-waste in landfills instead, e-waste must be recycled and recovered at prescribed or licensed premises, and disposal must take place on prescribed premises only and must be carried out in an environmentally sound manner. Therefore, the DOE has issued licenses to 18 full recovery facilities and 128 partial recovery facilities to convert various kinds of e-waste into source materials (Suja et al., 2014).

Various studies found that Malaysians have moderate knowledge about e-waste but their knowledge and practice on e-waste management are still lacking (Mahat et al., 2019, Kalana, 2010). The main issue relating to e-waste is the poor attitude towards e-waste management and recycling. For instance, according to Alias et al., (2014), most of the projects on e-waste management awareness among received lukewarm response due to their poor awareness of e-waste management issues and its consequences. Hence, poor e-waste knowledge, attitude, and practices may affect the e-waste management in Malaysia. This study will fill the gap in the area of e-waste management as there is yet a research conducted on e-waste management among business students in a public university. The research objectives of this study are to examine knowledge, attitude, and practices on e-waste management among business students in a public university.

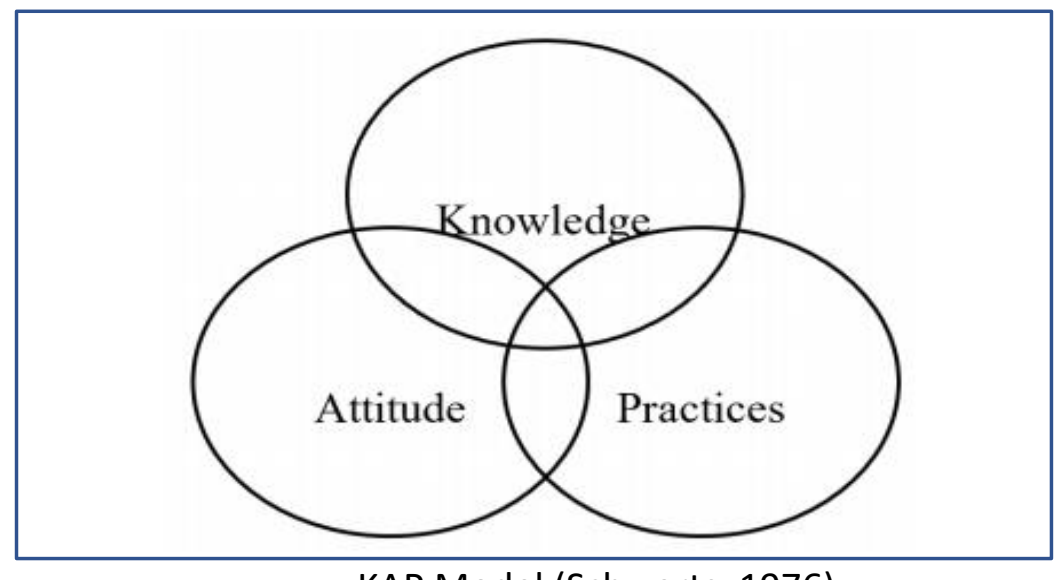

KAP Model (Schwarts, 1976)

Schwarts has introduced a model that emphasizes on the existence of awareness based on three elements which is knowledge, attitude and practices (KAP Model). Sabouhi et al., (2011) indicates that there is a relationship between awareness toward knowledge, attitude and practice where knowledge becoming main factors in the smart city of the future. This study employs KAP model in determining the knowledge, attitude, and practices of respondents in e-waste management in Malaysia.

\section{Research Methodology}

This study employs quantitative method in reaching its objectives. A set of questionnaires with 30 questions which include Likert's scale questionnaire is used. This 
questionnaire design was chosen to obtain data on e-waste management knowledge, attitude, and practices. Respondents are selected from one public university in Johor, focusing on business students that use electrical and electronic products such as mobile phone, laptop, and smart watches. Qestionnaire is distributed to 115 samples. The collected data is analyzed using Statistical Package for Social Science (SPSS). This software facilitates the research in analyzing data through descriptive statistical such as percentage results, mean score.

\section{Results and Discussions}

Result shows that $73 \%$ of female students and $27 \%$ male students responded to the questionnaire. Besides that, the highest percentage of respondents are Malay respondents (62.6\%), followed by Chinese respondents (17.4\%), Indian respondents (10.4\%), and Indonesian respondents (9.6\%). Other than that, the highest percentages of respondents are from ages $22-24$ years old ( $72.2 \%)$, followed by students $19-21$ years old (17.4\%), and students 25 and above years old (10.4\%).

Table 1 Mean Score for E-Waste Management Knowledge

\begin{tabular}{|l|c|c|}
\hline \multicolumn{1}{|c|}{ Variables } & Mean Score & Level \\
\hline E-waste management is important for environment sustainability. & 4.76 & High \\
\hline E-waste pollution will reduce landfill space. & 4.36 & High \\
\hline E-waste can cause environment pollution. & 4.30 & High \\
\hline E-waste pollution will affect human health. & 4.41 & High \\
\hline Electric and electronic device contain hazardous material. & 4.48 & High \\
\hline Did you know that our country provides a place to dispose E-waste? & 1.69 & Low \\
\hline Did you know which company manage E-waste in our country & 1.68 & Low \\
\hline
\end{tabular}

Table 2 Mean Score for E-Waste Attitude and Practices

\begin{tabular}{|l|c|c|}
\hline \multicolumn{1}{|c|}{ Variables } & Mean Score & Level \\
\hline Mobile phones can be recycled. & 3.72 & High \\
\hline $\begin{array}{l}\text { I prefer to trade-in my old mobile phone rather than buy a new } \\
\text { phone. }\end{array}$ & 3.37 & High \\
\hline My old electrical and electronic devices are correctly disposed. & 3.16 & High \\
\hline E-waste can dispose through 3R which "Reduce, Reuse and Recycle". & 4.10 & High \\
\hline Repair broken electric devices are one way to reduce E-waste. & 4.26 & High \\
\hline The rapidity of technology contributes to the increase in E-waste. & 4.47 & High \\
\hline $\begin{array}{l}\text { High demand for electrical and electronic products will affects the } \\
\text { increasing in E-waste. }\end{array}$ & 4.45 & High \\
\hline \begin{tabular}{l} 
E-waste management should be widely disseminated to the public. \\
\hline $\begin{array}{l}\text { I change the data storage in pen-drive, external hard disk, and disc } \\
\text { to cloud storage. }\end{array}$
\end{tabular} & 4.40 & High \\
\hline $\begin{array}{l}\text { E-waste contains precious metal like gold, copper, platinum, nickel, } \\
\text { aluminum and others. }\end{array}$ & 4.32 & High \\
\hline $\begin{array}{l}\text { E-waste needs to be managed more effectively to reduce the } \\
\text { environmental pollution. }\end{array}$ & 4.57 & High \\
\hline
\end{tabular}




\section{Discussion}

Based on the results, respondents have a high level of e-waste knowledge however the level of e-waste management is relatively low. The findings show that the overall level of the variables is higher which is between 3.65-5.00. This is aligned with previous study which stated that the knowledge on e-waste among Malaysians is high (Mahat et al., 2019). This result can also be supported by a study which stated that the level of knowledge and awareness amongst the public in Shah Alam is high but most respondents do not know about e-waste recycling in Malaysia (Nur et al., 2015). Apart from that, on the perspective of attitude and practice on e-waste management, result shows that the overall level of the variables is high level, which is the mean value is between 3.65-5.00 (refer Table 2). This clearly shows that the attitude of the business students towards e-waste management is at moderate level. This is totally contrary to the previous studies by Kalana (2010) which stated that the attitude of Malaysians towards e-waste management is still poor. Students should have knowledge about e-waste management. Improper e-waste management can give an effect to human health and the environment. Hence, knowledge, attitude and practice of electrical and electronic user is important to ensure e-waste management can be done effectively.

\section{Conclusion}

The study has explored and identified students' knowledge, attitude and practice of one public university on e-waste management in Malaysia. It is observed that business students in the said public university have a sound knowledge on e-waste however, the knowledge on e-waste management is still lacking. Besides, in view of the findings of this study, it has also identified that the students have a good attitude and practice in managing their e-waste.

\section{Theoretical and Practical Implications}

E-waste management is necessary in meeting global sustainable development goals for 2030, including reducing risk health complications and death due to hazardous and toxic composition in e-waste and exposure to the surrounding environment (Islam et al.,2021). Thus, identifying the knowledge, attitude and practice of electrical and electronic equipment among Malaysian consumers are essential in order to develop e-waste policy in the nation. This study contributes to the evolution of technology management theory and its relations to managing e-waste as it provides insight into knowledge, attitude and practice of public university business students in managing e-waste and how it will affect the management of e-waste in Malaysia. It is observed that through this study, it will assist the government in providing awareness about important of proper e-waste management among youth and it will benefit educational institution especially the public universities in form of curriculum development for business students. It is suggested that topic on e-waste management to be included in the curriculum syllabus for business students. Additionally, the findings provide valuable insights for policymakers developing e-waste management strategies among young consumers in Malaysia.

\section{References}

Alias, A. F., Ishak, M. B., Zulkifli, S. N. A. M., \& Jalil, R. A. (2014). E-waste management:An Emerging Global Crisis and The Malaysian Scenario. International Journal of Environmental Sciences, 4(4), 444. 
Ananno, A. A., Masud, M. H., Dabnichki, P., Mahjabeen, M., \& Chowdhury, S. A. (2021). Survey And Analysis Of Consumers' Behaviour For Electronic Waste Management In Bangladesh. Journal of Environmental Management, 282, 111943.

Awasthi, A. K., Li, J., Koh, L., \& Ogunseitan, O. A. (2019). Circular Economy and Electronic Waste. Nature Electronics, 2(3), 86-89.

Askari, A., Ghadimzadeh, A., Gomes, C., \& Ishak, M. B. (2014). E-waste Management: Towards an Appropriate Policy. European Journal of Business and Management, 6(1), 37-46.

Cao, J., Lu, B., Chen, Y., Zhang, X., Zhai, G., Zhou, G., \& Schnoor, J. L. (2016). Extended Producer Responsibility System In China Improves E-Waste Recycling: Government Policies, Enterprise, And Public Awareness. Renewable and Sustainable Energy Reviews, 62, 882-894.

Chibunna, J. B., Siwar, C., Begum, R. A., \& Mohamed, A. F. (2012). The Challenges of E-waste Management Among Institutions: A Case Study of UKM. Procedia-Social and Behavioral Sciences, 59, 644-649.

Department of Environment (Department of Environment). (2010). Akta Kualiti Alam Sekeliling 1974 (Akta 127). Peraturan-Peraturan Alam Sekeliling (Buangan Terjadual) 1989. 1 (1), 14-29.

Garlapati, V. K. (2016). E-Waste in India And Developed Countries: Management, Recycling, Business And Biotechnological Initiatives. Renewable And Sustainable Energy Reviews, 54, 874-881.

Islam, M. T., Dias, P., \& Huda, N. (2021). Young Consumers'e-Waste Awareness, Consumption, Disposal, And Recycling Behavior: A Case Study Of University Students In Sydney, Australia. Journal Of Cleaner Production, 282, 124490.

Kang, K. D., Kang, H., Ilankoon, I. M. S. K., \& Chong, C. Y. (2020). Electronic Waste Collection Systems Using Internet Of Things (lot): Household Electronic Waste Management In Malaysia. Journal Of Cleaner Production, 252, 119801.

Kala, K., \& Bolia, N. B. (2020). Waste Management Communication Policy for Effective Citizen Awareness. Journal of Policy Modeling, 42(3), 661-678.

Kalana, J. A. (2010). Electrical and electronic waste management practice by households in Shah Alam, Selangor, Malaysia. International Journal of Environmental Sciences, 1(2), 132-144.

Mahat, H., Hashim, M., Nayan, N., Saleh, Y., \& Norkhaidi, S. B. (2019). E-waste disposal awareness among the Malaysian community. Knowledge Management \& E-Learning: An International Journal, 11(3), 393-408.

Masud, M. H., Akram, W., Ahmed, A., Ananno, A. A., Mourshed, M., Hasan, M., \& Joardder, M. U. H. (2019). Towards the Effective E-waste Management In Bangladesh: A Review. Environmental Science And Pollution Research, 26(2), 1250-1276.

Nur Syazwina, K. (2019) Assessment of awareness in mobile phone waste recycling program among consumers in Kuala Lumpur, Masters thesis, University of Malaya.

Sabouhi, F., Babaee, S., Naji, H., \& Zadeh, A. H. (2011). Knowledge, awareness, attitudes and practice about hypertension in hypertensive patients referring to public health care centers in Khoor \& Biabanak. Iranian Journal of Nursing and Midwifery Research, 16(1), 34-40

Schawrtz, N. (1976). Nutrition Knowledge, Attitude and Practices of Canadian Public Health Nurses. Journal of Nutrition Education, 8(2), 28-31

Suja, F., Abdul Rahman, R., Yusof, A., \& Masdar, M. S. (2014). E-waste Management Scenarios in Malaysia. Journal of Waste Management, 2014. 
INTERNATIONAL JOURNAL OF ACADEMIC RESEARCH IN BUSINESS AND SOCIAL SCIENCES

Vol. 11, No. 8, 2021, E-ISSN: 2222-6990 @ 2021 HRMARS

Sarath, P., Bonda, S., Mohanty, S., \& Nayak, S. K. (2015). Mobile Phone Waste Management and Recycling: Views and Trends. Waste Management, 46, 536-545. 